\title{
Sob as bênçãos da I greja: o casamento de escravos na legislação brasileira
}

\section{With the Church blessings: the marriage of slaves in the Brazilian legislation}

\section{Adriana Pereira Campos Patrícia M . da Silva M erlo}

N este artigo discutiremos os parâmetros legais do casamento escravo no Brasil. Em conexão com esse assunto, explicitaremos o percurso do matrimônio na história legal portuguesa, canônica e brasileira até o Brasil I mpério. $\mathrm{N}$ a verdade, desde a década de quarenta do século passado, diversos estudos passaram a ocupar-se das relações entre legislação e escravidão nas sociedades americanas. ${ }^{1}$ Frank Tannenbaum, um dos pioneiros nesse empreendimento, chamou a atenção para a influência da tradição legal nas sociedades escravistas do Novo M undo no seu livro Slave and citizen. ${ }^{2}$ Consoante sua interpretação, a A mérica colonizada pelas metrópoles ibéricas, por ser herdeira da tradição legal romana, haveria dispensado aos escravos um tratamento mais humano do que aquele verificado nas colônias britânicas. U ma vez que a escravidão em Roma não possuía qualquer dimensão racial, sua tradição jurídica, quando transplantada para o continente americano, teria dado origem a uma legislação com fraca conotação racista. Em contraposição, os colonosingleses, sem nenhum lastro de jurisprudência escravista, criaram uma cultura jurídica especialmente voltada para o cativo negro, tornando assim o fator racial um elemento intrínseco do direito escravo norte-americano, o SlaveLaw. D eacordo com Tannenbaum, as diferenças da escravidão praticada nas Américas possuíam, portanto, uma profunda base histórica. ${ }^{3}$ 
0 contraste, portanto, entre os sistemas escravistas de Espanha e Portugal, de um lado, e o da Inglaterra e dos Estados Unidos, de outro, era profundamente marcado, e não meramente em seu efeito sobre 0 escravo, mas, até mesmo de forma mais significativa, sobre o status moral e social do homem liberto. Sob a influência da lei e da religião, o contexto social nas colônias espanholas e portuguesas provia espaço para os negros que passavam da escravidão à liberdade. A antiga tradição mediterrânea de defesa do escravo, combinada com a experiência latino-americana, havia preparado um ambiente no qual o negro liberto da escravidão poderia se inserir sem penalização visível. A própria escravidão não carregava marca. Ela era uma desgraça que recaíra sobre um ser humano, sendo em si mesma suficientemente opressiva. Tanto a Religião quanto a Lei desaprovavam quaisquer tentativas de transformá-la numa forma de opressão adicional. ${ }^{4}$

Essa e outras formulações do gênero ensejaram uma série de pesquisas sobre tal paradigma na evolução dos sistemas escravistas americanos, que evoluíram, com o tempo, para a crítica de tais teses. O s questionamentos dirigiram-se, sobretudo, à desmistificação da pretensa humanidade no tratamento legal dispensado aosescravosnas colônias ibéricas. Buscou-semostrar que, de fato, a legislação dessas áreas não houvera sido tão condescendentequanto seimaginava original mente. 0 esforço daliteratura revisionista, contudo, não foi suficiente para derrubar o pressuposto de os tratamentos legais dispensados aos escravos comportarem dois grandes casos paradigmáticos nas Américas: o primeiro seria a cultura jurídica romana legada às sociedades latino-americanas e, o segundo, o direito desenvolvido nas regiões de cultura inglesa.

É certo que as legislações portuguesas preservadas pela jovem nação brasileira formaram os elos de permanência do direito colonial na nova era. Entrementes, o direito romano constituiu-seainda a principal referência de definição legal da escravidão no Brasil. N a verdade, muito antes da existência das possessões portuguesas em território americano, o direito luso já se encontrava fortemente influenciado pela tradição romana, a qual, mesmo diante do ataque dos racional istas, permaneceu como sua principal fonte doutrinária. Além disso, a escravidão experimentada em Portugal não tinha raízes exclusi vamente raciais, daí a ad equação do direito escravo romano às necessidades do país. O sjuristas brasileiros entraram em contato com essa 
cultura legal por meio da sólida formação recebida, primeiramente em Coimbra - nos tempos de Colônia - e, posteriormente, em São Paulo e Recife- apósalndependência. ${ }^{5}$

N essesentido, 0 D ireito empregado na regulação social da escravidão no Brasil guarda importantes componentes da tradi ção legal lusitana e, por conseqüência, romana, elementos em evidênciana análisedeTannembaum..$^{6} \mathrm{Em}$ relação ao matrimônio, essa herança alcança a formação do D ireito C anônico ea tradição religiosa católica. 0 s casamentos dos escravos no Brasil obedeceram ao processo de imposição de um regime e uma disciplina religiosa aceita desde os primeiros tempos pel os portugueses. Com efeito, o presente artigo tem como propósito discutir a legislação a respeito de casamentos entreescravos eentre escravos elivres a partir dessa culturajurídica. Trata-se de uma primei ra aproximação desse objeto, pois há muitas referências sobre 0 assunto. $\mathrm{N}$ a tentativa de cumprir tal intento, levantou-se o ordenamento legal em vigor até a instauração da República, procedendo-se à leitura da legislação civil que, até 1916, obedecia ainda às ordenações portuguesas intituladas de Filipinas. Como aquela normatização lusitana fora precedida por duas outras, a Afonsina e a M anuelina, buscou-se fazer uma comparação com esses diplomas legais. Procedeu-se, além disso, a uma investigação a respeito do assunto nas normas eclesiásticas, sobretudo nas decisões emanadas do Concílio de Trento e as Constituições Primeiras do Arcebispado da Bahia. Tais leis canônicas concorriam, na verdade, com as disposições civis contidas nas ordenações lusas na disciplina do matrimônio no Brasil desde os tempos coloniais e permaneceram influentes mesmo após a Independência. A meta foi arrepanhar o maior subsídio possível para conhecer a instituição matrimonial que vigeu até o Império. Ademais, ao longo de todo 0 artigo, cotejaram-se as observações legais com verificações nos registros paroquiais de Vitória/ES, no século XIX, de união entre escravos e entreescravose livres com o objetivo de apresentar al gumas pistas empíricas da aplicação dos procedimentos legais impostos aos enlaces matrimoniais.

\section{Legislação portuguesa e escravidão no Brasil}

Como a legislação a respeito do matrimônio de escravos no Brasil relaciona-secom todo 0 ordenamento relativo à escravidão, convém escla- 
recer que o conjunto deleis voltado à servidão tem importantes elementos herdados da tradição jurídica trazida pel os colonizadores portugueses. Afinal, mesmo apósa I ndependência, grande parte da legislação eda estrutura de $D$ ireito lusitanas foi recepcionada pela nova ordem. ${ }^{7}$ A colonização fortemente centralizada deixou marcas profundas não só na formação de todo o sistema de leis do país, como também em toda a organização burocrática, particularmentea judiciária. Todo o aparato administrativo implantado na colônia pautava-se por um corpo deleis de origem metropolitana. D eacordo com Arno e M aria José Wehling, "[...] não devemos supervalorizá-la [lo]: havia um abismo entre o país formal, existente nas normas jurídicas públicas e privadas, eo país real daC olô-nia". ${ }^{8}$ Assim, encontramos procedimentos e expedientes próprios dos brasileiros e somente a el es aplicáveis. Especificamente, a instituição do matrimônio recepcionou, ainda na fase colonial, umalei canônica particular intitulada Constituições Primeiras do Arcebispado da Bahia, que proporcionou a entrada do elemento escravo na disciplina do sacramento do casamento no credo católico.

$\mathrm{N}$ o entanto, a influência da tradição legal portuguesa enraizou-se no Brasil, mesmo após o desligamento de Portugal, recepcionando a recémautônoma nação grande parte do antigo ordenamento da ex-metrópole. As O rdenações Filipinas, em especial, formavam o escopo da legislação lusa que prevaleceu por mais tempo entre os brasileiros do que entre os próprios portugueses. ${ }^{9}$ Esse monumental corpo de leis representava, consoante Lacombe, o coroamento da obra entregue aos legistas para a edificação de uma "base teórica, na qual seapoiasse todo o processo político, originandose um conjunto de princípios próprios à fase de passagem, das concepções medievais, para as idéias modernas concernentes ao Estado". ${ }^{10}$ Embora objetivassem criar uma lei nacional em substituição ao direito erudito e canônico aplicado indistintamentena Europa, as 0 rdenações permaneceram com clara inspiração romana, aplicando subsidiariamentenas decisões judiciais vários dispositivos romanos etornando-os a matriz teórica do D ireito Português aplicado na colônia. ${ }^{11}$

O Direito Canônico, os costumes e ajurisprudência também compunham o complexo conjunto deleis. As autoridades político-administrativas orientavam-se também por regimentos, instruções, decretos, provisões, portarias, consultas eal varás. O shistoriadores, em geral, condenam como 
confuso esse emaranhado de leis e atos administrativos. Talvez o sentido desse estado de coisas fosse a ambigüidade característica da modernidade operada em Portugal, já que, por um lado, criou-se um Estado centralizado, mas, por outro, foram firmementemantidos os valores e privilégios de uma sociedade estamental. ${ }^{12}$ Vejamos o que afirma Rubem Barbosa Filho:

[...] se nossa investigação estiver presidida por um modelo de relação Estado-sociedade tal como sintetizada na díade hobbesiana do indivíduo e do Estado, as conclusões poderiam apontar a resistência das formas do passado. Se, contudo, a procura se orientar pela hipótese de que a Ibéria exercitava uma alternativa autônoma e também moderna de organização do poder e da sociedade, os ganhos poderiam ser maiores e mais instigantes. Estaríamos, neste caso, procurando o que a I béria queria continuar a ser - uma sociedade arquitetônica e pluralista - e não 0 que deveria ter sido na perspectiva de um modelo de 0 cidente e modernidade que se transformou em hegemônico. ${ }^{13}$

Embora o processo de codificação das leis no período moderno seja tradicionalmente abordado apóso período de criação do CodeC ivil francês (1804), os reinos ibéricos experimentaram a sistematização muito antes dos outros países europeus. Todavia, a codificação das leis nesses reinos não significou a imposição de limitações ao poder monárquico. Ao contrário, a obra desistematização dasleisna Península I bérica serviu, desdemuito cedo, ao propósito de justificar a presença dos bárbaros como dirigentestambém da população romana. Enquanto na França C lóvis utilizava o batismo para legitimar-se como rei, os visigodos retomavam a tradição jurídica romana por meio do Breviarum Alarici ou Lex Romana wisigothorum, ${ }^{14}$ invocado noutros lugares como Interpretativo do Código Teodosiano. $\mathrm{N}$ a Ibéria, permaneceu em vigor até meados do século VII, quando foi suplantado pelo liber iudiciorum, em castelhano o Fuero Juzgo, com os germes da estrutura feudal que regeria por muitos séculos a vida judiciária ibérica. Fortemente romanizada, a liber foi promulgada em 654, pelo rei visigodo Recesvinto, sendo aplicada a todos os habitantes do reino. Continuou a ser invocada, senão aplicada, pelo menos na parte da Península I bérica não arabizada, até o século XII.

N os séculos XII e XIII, surgiram na Península I bérica os primeiros textos de costumes locais ou regionais com caráter territorial e não apenas 
pessoais, como os códigos anteriores, que diziam respeito aos súditos de determinado reino. N umerososforais, fueros, pequenos códigos particulares, eram concedidos pelos reis às diferentes vilas, cidades e municípios. $\mathrm{N}$ ote-se, entretanto, que essa pluralidade de leis locais convivia com uma variedade de leis pessoais e, por exemplo, em Toledo, após a reconquista, regiam cinco direitos diferentes. ${ }^{15} \mathrm{D}$ aí o ímpeto de sistematização das leis que tomou conta da penínsulana Baixal dadeM édia eno período moderno.

Em meados do século XIII, Afonso X aparece com o El fuero Real de España, reproduzindo a rigorosa proibição de aplicar outras leis do antigo Fuero Juzgo sob pena de multa. Todavia, sua obra mais célebre foi as Siete Partidas ${ }^{16}$, terminadas em 1263, mas somente promulgadas por Afonso XI nas $\mathrm{C}$ ortes de Alcalá, que preservava a absoluta territorialidade. ${ }^{17}$ Adeline Roucquoi asseveraque

[...] No fim do século XIII, o rei D. Dinis de Portugal [1279-1325] mandou traduzir para português as Partidas do seu avô. No reinado de $D$. Pedro I (1357-1367), o reino foi dotado de um Livro das Leis e Posturas, compilação de cerca de 370 disposi çoes legais, que as 0 rdenações Afonsinas completaram em 1446 e que sistematizavam o quadro jurídico portuguese ${ }^{18}$

Em Portugal, atéfins do século XIII, identificam-secerca de 250 leisposturas, estabelecimentos, ordenações, degredos e, raramente, constituições. Consoante H espanha, cerca de 220 desses diplomas foram produzidos entre 1248 e $1279 .{ }^{19} \mathrm{C}$ onquanto as 0 rdenações Filipinas tratassem a escravidão como uma matéria cotidiana, importa salientar que as disposições legais sobre 0 assunto eram limitadas. Tem razão Alan Watson ao afirmar que as 0 rdenações não chegaram a dar forma a um estatuto de escravidão..$^{20} \mathrm{~A}$ parentemente, nem as $\mathrm{C}$ ortes utilizaram o costume para regular um Direito para os escravos em Portugal. Em conseqüência, 0 Direito Romano - Corpus Juris Civilis - era diretamente utilizado na solução dos problemas relacionadosà escravidão, formando o escopo do sistemajurídico português voltado aos escravos. Então, quando as colôniasforam incorporadas a Portugal e a escravidão se tornou a forma de trabalho corrente, já existia um D ireito ao qual sepodia recorrer: 0 D ireito Romano. ${ }^{21}$

Entretanto, em relação à temática do matrimônio de escravos, as ordenações tornavam a matéria ain da mais restrita, ocupando-se, quando mui- 
to, de questões relacionadas ao adultério, ao concubinato e à sucessão, ${ }^{22}$ deixando a questão dos enlaces aos cuidados do direito canônico. D esse modo, como severá, o conúbio no Brasil, mesmo obedecendo inicialmente às tradições portuguesas no tempo colonial, paulatinamente sofrera a intervenção eclesiástica, pois elevado fora em nível de sacramento pelo sínodo de Trento. A pós as intervenções da I greja católica desde o século XVI, a associação conjugal no Brasil constituirá um campo normativo privilegiado do direito canônico atépelo menos o século XIX, guiando-sepor seu regimedisciplinar.

\section{0 regime matrimonial legado à América}

Antes deabordar o conceito legal de casamento, necessário compreender que o Direito Romano legado ao mundo ocidental foi obra dos bizantinos eda época medieval, assim como o moderno conceito de matrimônio.

D e Constantino a Justiniano (dos séculos IV ao VI), assistiu-se aos monumentais esforços de codificação que reuniram as obras dos jurisconsultos romanos e constituições imperiais, além do direito vulgar nascido de costumes novos e fixado pelos legisladores. ${ }^{23} \mathrm{D}$ ois desses códigos obtiveram importância no ocidente medieval: 0 Código Teodosiano e o Código Justiniano, esteúltimo denominado posteriormentedeC orpusjuriscivilis. De acordo com essas legislações, o matrimônio constituía-seem uma convenção puramenteconsensual, despida dequal quer formalismo, que não exigia nem mesmo a coabitação: $N$ uptiasnon concubitus, sed consensusfacit. ${ }^{24}$

0 Cristianismo alterou os costumes em torno do conjúgio, promovendo, inicialmente, al gumas formalidades como o compromisso solene entre os esponsais, a entrega de um dote pelo noivo à noiva, a consagração do ato por um representante da I greja e a entrega da noiva pelo pai. D os séculos X ao XVI, a I greja assumiu completamentea regulação do desposório por meio do Direito Canônico. As contendas relativas ao consórcio resolviam-se nos tribunaiseclesiásticos que possuíam a competência sobreo assunto. ${ }^{25}$

$D$ eacordo com o $D$ ireito $C$ anônico, reconhecia-seo casamento como sacramento desde, pelo menos, os séculos XII e XIII. Assim, o divórcio tornou-se um problema para a Igreja. Consoante 0 historiador John 
Gilissen, ${ }^{26}$ a solução para a instituição do divórcio ensejou o conceito da indissolubilidade do matrimônio, uma vez quesomenteseria admitido para bodas não consumadas. D essa forma, a I greja adotara, a partir de então, 0 princípio dequea validade do conúbio dependia não somentedo consentimento dos esposos, assim como da copula carnalis, en quanto elemento essencial ao ajuntamento matrimonial. ${ }^{27} \mathrm{D}$ esse modo, a indissolubilidade da união entre um homem e uma mulher, além das formalidades da I greja, dependia da consumação, sem a qual tornava-se incompleta e passível de divórcio.

Para evitar a clandestinidade, em 1215, o Concílio de Latrão expressamente condenou como pecado o casório sem bênção nupcial ou publicação dos banhos an unciando o enlace. As sanções, embora adstritas ao $D$ ireito C anônico, denunciavam a firme posição da I greja em dirigir a instituição do himineu da cristandade ocidental. Consta, todavia, a continuidade de casamentos clandestinosna Europa até, pelo menos, o século XVI. 0 matrimônio aguardou até 0 Concílio de Trento para se consolidar como uma instituição sagrada do cristianismo ocidental, definindo o delineamento passado ao mundo contemporâneo. ${ }^{28}$

\section{O Concílio de Trento e a elevação do matrimônio a sacramento}

O Concílio deTrento, por suas decisões na esfera do dogma eda legislação eclesiástica, transcendeu os objetivos a que se propunhae condicionou a futura evolução do catolicismo em todo o mundo religioso. Esse sínodo constituiu-seno $19^{\circ}$ concílio ecumênico da I greja C atólica e desenvolveu-se em três fases principais, entre 1545 e 1563. A reunião de legados papais, bispos, cardeais, teólogos egerais de ordens pôsfim a um período de desorientação dos fiéis e graves irregularidades na gestão temporal da I greja e marcou, segundo Gilissen, o início de uma etapa de clareza doutrinária, disciplinae central ização queculminaria maistardeno Concílio Vaticano I. ${ }^{29}$

\subsection{A realização do Concílio de Trento}

A I greja Católica vivia um processo de crise, agravada sobretudo a partir do século XIV. A transferência da sede papal para Avignon e o cisma do 
O cidente haviam solapado a autoridade pontifícia. O s papas do Renascimento, que pouco se ocupavam da doutrina, mantinham uma cortesecularizada, em que predominavam as disputas políticase o nepotismo. 0 quinto Concílio de Latrão (1512-1517) não fora capaz de instituir as mudanças necessárias e, no mesmo ano de seu encerramento, Lutero proclamou em W ittenberg, em outubro de 1517, as 95 teses que deram origem à R eforma protestante.

A urgência da mudança tornou-se evidente com as manifestações sucessivasna Inglaterra, Países Baixos, Alemanha eSuíça, mas o Papa ClementeVII temeu não só a repetição dasturbulênciasocorridas em concílios anteriores, como as pressões políticas do imperador Carlos V. No entanto, seu sucessor, Paulo III, estava convencido de que a unidade cristã e uma eficaz reforma da I greja somente se efetivariam com a realização de um concílio. D epois dealgumastentativasfrustradas, convocou-seuma reunião em Trento, no N orte da I tália, com início em 13 de dezembro de $1545 .{ }^{30}$

$\mathrm{N}$ a primeira etapa do concílio, prolongada até 1547 , fixaram-se as Sagradas Escrituras ea tradição como as fontes da revelação divina. Estabeleceu-seo cânon dos textos bíblicos; definiu-se também a doutrina sobreo pecado original etratou-se do problema da justificação pela fée pelas boas obras. N a segunda etapa, entre 1551 e1552, sob o pontificado de úlio III, os delegados finalizaram os decretos sobrea eucaristia, definindo a doutrina da transubstanciação; a confissão, que foi amplamenteesclarecida; ea disciplina clerical. 0 concílio foi obrigado a dissolver-se mais uma vez por problemas políticos emilitares. 0 papa seguinte, Paulo IV, não quis reiniciá-lo por julgá-lo condescendenteediplomático edeu início pessoalmenteauma drástica reforma da disciplina na I greja. Pio IV, que assumiu o papado em 1559, instal ou a terceira e última fase do concílio, quando se adotaram dispositivos doutrinários e dogmáticos como os decretos sobre comunhão, missa, matrimônio, ordens sagradas e indulgências. Como assevera $\mathrm{N}$ ader:

... o Concílio de Trento incluiu o casamento definitivamente dentro do pensamento católico como um instrumento sagrado, necessário e uniformizado. As determinações canônicas fundamentais sobre a contratação do matrimônio subordinaram-no clara e indistintamente à jurisdição da Igreja, principalmente porque havia sido oficialmente declarado um dos 
sete sacramentos. O Concílio assumiu a iniciativa de sua ordenação e promulgou-a como lei para a Igreja Universal. ${ }^{31}$

D issolvido o concílio em 1563, o papa confirmou seus decretos em 1564 e reuniu suas disposições no volume intitulado Profissão da Fé Tridentina. Pouco tempo depois, surgiu o catecismo deTrento. 0 missal e o breviário foram revistos e publicou-se uma nova versão da Bíblia. Até o final daquele século, muitos dos abusos que motivaram a R eforma protestante haviam desaparecido ea I greja C atólica recuperara muitos seguidores na Europa. 0 concílio, porém, não foi capaz de superar a cisão na igreja cristã. ${ }^{32}$

\subsection{O sacramento do casamento no Concílio de Trento}

Retomando a questão do matrimônio, vale destacar que, dentro do projeto de renovação da I greja formulado em Trento, constituía-sena principal característica a cooperação do indivíduo com D eus ea fé cristã, devendo ser mais bem vivenciada na atividade terrena. O sconciliares entenderam quea vontade humana não era meramente passiva nem escrava do pecado, massim, como afirma $D$ avidson ${ }^{33}$, convocada a colaborar com a obra divina. $D$ entro dessa perspectiva, decidiram que, embora em si mesma não fosse um obstáculo intransponível, a concupiscência levava ao pecado. Em vista disso, e para evitar o pecado do desejo da carne, somente a união conjugal controlada pela I greja seria a solução.

Em conseqüência dessas decisões, instruíram-se medidas, como o D e creto de reformati onematrimonti, disciplinando as relações sexuais dos indivíduos e, a principal delas, o casamento sacramental, ferramenta de luta para pessoas que não conseguiam viver em castidade. Assim, o matrimônio tornou-se uma instituição obrigatória, dentro de moldes bem definidos, que deveria realizar-se na presença de um pároco ou de um vigário. ${ }^{34}$ É importante considerar que embora a I greja, desde tempos remotos, considerasse o casamento como uma união profana, o C oncílio deTrento consagrou-Ihe uma nova disciplina, organizando-o como uma cerimônia eclesiástica que representava a única, a perfeita e a verdadeira união cristã, ${ }^{35}$ absolutamente diferenciada da dos ritos populares. ${ }^{36} \mathrm{O}$ bserve 0 texto do próprio concílio: 
970. Visto que o matrimônio da Lei Evangélica excede pela graça de Cristo os antigos matrimônios, com razão ensinaram os nossos santos Padres, os Concílios e toda a Tradição da I greja, que ele deve ser enumerado entre os sacramentos da $\mathrm{N}$ ova Lei. Contra esta doutrina se levantaram furiosos neste século certos homens ímpios, que não só tiveram opiniões erradas sobre este sacramento venerável, mas ainda, como costumam, introduziram a liberdade da carne sob pretexto de Evangelho, afirmando, por escrito e oralmente, muitas doutrinas alheias ao sentir da I greja C atólica, à Tradição, aprovada desde o tempo dos Apóstolos, e isto não sem grande dano dos fiéis de C risto. 0 ra, querendo este santo e universal Concílio atalhar a sua temeridade, julgou se deviam pôr à luz as principais heresias e erros dos sobreditos cismáticos [...]. ${ }^{37}$

0 casamento tridentino passou a ser um contrato elevado à dignidade de sacramento por meio de 12 cânones, ${ }^{38}$ subordinado à cerimônia oficial, cuja liturgia deveria ser uniformizada ecel ebrada pelo pároco em presença de duas ou mais testemunhas, diante dos quais os noivos deveriam proferir as palavras de aceitação do enlace. A concepção do matrimônio como sacramento acentua o mútuo consentimento dos cônjuges, expresso por palavras e sinais. 0 snubentes deveriam ministrar o sacramento, na presença de testemunhas. ${ }^{39}$ Assim,

992. O santo C oncílio declara completamente inábeis para contrair matrimônio os que tentarem fazêlo de outro modo que não na presença do pároco (ou de outro sacerdote delegado pelo pároco ou pelo O rdinário) e duas ou três testemunhas. Tais contratos os dá por írritos e nulos, como com efeito os invalida e anula por este decreto. ${ }^{40}$

Buscando validar uma união conjugal, os noivos não precisavam do consentimento dospais, poiso Concílio dispensava essa autorização, levando em consideração apenas os sentimentos dos noivos. Eles deveriam cuidar para quenão houvesse entresi nenhuma ligação de parentesco consangüíneo até o quarto grau, além de outras tantas normas que poderiam propiciar a nulidade do consórcio. ${ }^{41}$ In verbis:

990. Embora não se deva duvidar que os matrimônios clandestinos, realizados com o consentimento livre dos contraentes, sejam válidos e verdadeiros, enquanto a I greja não os declarar nulos (írritos), devendo, portanto, ser condenados - como de fato os anatematiza o sacro Conci- 
lio - os que negam a sua validade, e os que falsamente afirmam ser inválidos os matrimônios contraídos pelos filhos sem o consentimento dos pais, como se dependesse dos pais fazer o casamento válido ou nulo, contudo, apesar disso, a Santa I greja sempre os tem detestado e proibido, movida por justíssimas causas [... ${ }^{42}$

Conservando a doutrina clássica de união, em que a cerimônia constituía-se em um ato meramente consensual entre os interessados, o C oncílio prescreveu também o pregão do banho, diretamente pelo pároco, em três domingos consecutivos: o registro do nome dos nubentes e das testemunhas; a data e o local, de forma a comprovar o ato pleno da união; e a solenidade de bênção nupcial que deveria encerrar o enlace. Estabeleceu, ainda, al gumas normas para os casamentos real izados fora dos padrões, mas autorizados pel os bispos, ${ }^{43}$ assim como a proibição da maridagem de sacerdotes. $\mathrm{N}$ esse sentido pregava o concílio:

990. [...] Sabendo o santo Concílio que aquelas proibições já não surtem efeito devido à desobediência dos homens, e ciente de que se cometem graves pecados, cuja origem reside nos matrimonios clandestinos, especialmente por parte dos que estão em estado de excomunhão, pois, tendo abandonado a primeira mulher, que fora desposada às ocultas, unem-se às claras com outra, passando a viver com ela em perpétuo adultério; e não podendo este mal ser obviado pela I greja, que não julga o oculto, a não ser pelo uso de um remédio mais eficaz, manda este santo Concílio, seguindo as normas do Q uarto Concílio de Latrão, celebrado sob Inocêncio III, que para o futuro, antes do casamento, o próprio pároco dos contraentes proclame três vezes publicamente os que vão contrair, em três dias festivos contínuos, durante a missa. Corridos os pregões, e não se apresentando legítimo impedimento, proceda-se ao matrimonio em face da I greja, onde o pároco, após interrogar o homem e a mulher, se receber o mútuo consentimento, diga: Eu vos uno em matrimônio, em nome do Padre, do Filho e do Espirito Santo, ou use de outras palavras, segundo 0 rito de cada província. ${ }^{44}$

O sacramento, assim, possuía significação transcendente, um efeito e um caráter divinos, como meio de graça esantificação. A repercussão detais decisões obrigou que as nações ibéricas recepcionassem o ordenamento tridentino, mesmo diante do grande movimento de imposição exclusiva das normas pátrias em seus reinos. Em Portugal, ${ }^{45}$ em 15 de setembro de 
1564, elaborou-seum decreto recebendo as determinações do Concílio de Trento. ${ }^{46}$

\subsection{0 matrimônio na legislação portuguesa}

Em relação aos efeitos da sacralização dos casamentos, jazia implícito no conceito de família que os cônjuges tinham os mesmos direitos e deveres recíprocos, os mesmos efeitos patrimoniais, as mesmas faculdades dos filhos na sucessão dos bens. I gualmente, $0 \mathrm{D}$ ireito $\mathrm{C}$ anônico garantia a validade religiosa do ato eseus efeitos, além do caráter de sacramentalidadee indissolubilidade. M esmo após o Concílio deTrento, coexistiam na I béria trêsformas de conjúgio: 0 casamento de bênção ${ }^{47}$, a união de pública fama ${ }^{48} \mathrm{e}$ 0 conúbio dejuras ${ }^{49}$. Encontrava-se assim registrado nas 0 rdenações Filipinas: " TÍT ULO XIX - D o homem, que casa com duas mulheres, e da mulher, que casa com dous maridos. [sic] - crime de bigamia". Esse comando pode ser encontrado no Títul X XIII das Afonsinas que somentemencionava o homem casado com duas mulheres ou com sua criada eno T ítulo XIX das M anuelinas com mesmo teor.

D esse modo, segundo os costumes ou foros, tanto os casados com a bênção da I greja, como os casados de juras, tinham igualmente obrigação de viverem juntos e guardarem mutuamente fidelidade. Prescreviam as O rdenações que

Título LXVI. Se algum homem casado der a sua barregã alguma coisa móvel ou de raiz, ou qualquer outra mulher [...] sua mulher poderá revogar e haver para si a coisa que assim foi dada e mandamos que seja recebida em Juízo a demandar a dita coisa sem autoridade e procuração do marido $[\ldots]^{50}$

A mulher, casada segundo qualquer dessas modal idades de matrimônio, que abandonasse o marido, devia ser deserdada. Todo aquele que a protegesse durante 0 abandono do domicílio conjugal, pagaria ao marido uma multa proporcional ao tempo da ausência. D e semelhante modo, 0 marido que abandonasse a mulher seria compelido pel os alcaides, sob instância do bispo, a juntar-se denovo com ela.

Tanto o marido casado frenteà I greja como o casado clandestinamente podiam impunemente matar a mulher adúltera e o seu cúmplice, sem 
que por esse fato sofressem com a inimizade ou o direito de vingança da família do morto. Se o homem quisesse repudiar a adúltera, deveria primeiro garantir-Ihe competentemente todos os seus direitos e se depois a quisesse receber novamente, deveria restituir-lhe outra vez o dotee as arras.

Achando o homem casado sua mulher em adultério, licitamente poderá matar assim a ela como ao adúltero, salvo se o marido for pião e o adúltero for fidalgo ou nosso desembargador, ou pessoa de maior qualidade. Porém, quando matasse alguma das sobreditas pessoas, achando-a com sua mulher em adultério, não morrerá por isso, mas será degredado para África $[. . .]^{51}$

$\mathrm{N}$ a verdade, a maior parte das normas relativas ao matrimônio no livro IV das O rdenações disciplina a sucessão e a herança e no livro V, os crimes de adultério. A respeito dos problemas advindos das relações conjugais ou extra-conjugais, as ordenações previam:

Todo homem, de qualquer qualidade que seja, que dormir com alguma mulher que andar em nossa casa ou casa da rainha, ou do príncipe, perderá toda sua fazenda, a metade para nossa Câmara e a outra para os Cativos $[\ldots]$

2. E se pela dita maneira entrar para dormir com escrava branca de guarda que esteja das portas adentro, haverá as ditas penas crimes, ora dormisse com ela, ora não. ${ }^{52}$

A companhando o D ireito C anônico, em especial, ordenamento emanado do C oncílio deTrento, as 0 rdenações prescreviam

Q ue todo homem que outrem viver, que por soldada quer a benfazer, e com a filha, mãe, irmã, tia, parenta ou afim, dentro do quarto grau contado segundo direito canônico daquele ou daquela com que viver, [...] morra por isso morte natural, ou the seja recebida defesa por dizer que era casado com a dita criada, e que casou fora de casa do seu senhor, como se provar que dormiu com ela em casa de seu senhor ou fora, ora a criada estivesse pro soldada, ora a bem-fazer..$^{53}$

C omo se vê, a legislação portuguesa absorvera o conceito canônico de matrimônio e sua legislação apoiava-seinteiramente nesses princípios. Todavia, a disciplina do casamento não constava no ordenamento lusitano, 
mas sim no corpo das leis eclesiásticas, em tributo ao reconhecimento da I greja como a guardiã dos enlaces conjugais. Pode-se observar, inclusive, no Livro $\mathrm{V}$ das $\mathrm{O}$ rdenações Filipinas uma sorte de comandos relacionada às infrações ao sacramento, que resultavam em penas gravíssimas como degredos, mortes, indenizações etc. Isso se devia ao pouco cumprimento dos rituais sacralizados. ${ }^{54}$

Não édifícil imaginar a freqüência com queas relações maritais também não se constituíam segundo o modelo de Trento no Brasil, como indica Vainfas em seu Trópico dos Pecados5:

Às mancebas índias dos primeiros lusitanos somar-seiam as negras, mulatas, mamelucas e mesmo as brancas pobres nos séculos XVII e XVIII. A falta de mulheres "brancas e honradas" - para usarmos a expressão de Fernão Cabral em 1592 - e a convicção que tinham os portugueses de seus privilégios sexuais, mesmo se casados, leva-los-iam cada vez mais para 0 mundo do concubinato. ${ }^{56}$

D aí a importância das Constituições Primeiras do Arcebispado da Bahia ${ }^{57}$ promulgadas em 1707, no acolhimento às orientações do Concílio de Trento, dedicando inclusive parte significativa de seu texto às questões referentes ao sacramento do matrimônio. Como o Brasil, nesseperíodo, constituía-senuma importantecolônia escravista, houvea preocupação em disciplinar inclusivea união entre cativos, cujos contornos não estavam estabele cidos pelo catolicismo europeu. Embora a sociedade brasileira não houvesse necessitado criar legislações específicas a respeito da escravidão tal como as colônias inglesas ou francesas graças aos institutos dos direitos romano e lusitano, o conúbio de escravos suscitou a adaptação das normas canônicas à convivência com a servidão vigente. D esse modo, a completa compreensão da disciplina religiosa em relação ao enlace matrimonial entreescravos no Brasil depende da análise do importantediploma criado pelo Arcebispado da Bahia em 1707.

\section{0 matrimônio nas Constituições Primeiras do Arcebispado da Bahia}

Para compreendermos de que maneira os cativos foram acolhidos no que tange à matéria do matrimônio no Brasil, podemos nesse momento 
passar à análise do principal documento eclesiástico que regulava o casamento, especificamente ao consórcio de cativos: as ConsituiçõesP rimeirasdo Arcebispado da Bahia... em vigor a partir de 1707. Suas orientações valiam para toda a colônia. Segundo esseregulamento, que evocava o direito divino e humano, os escravos podiam unir-se com pessoas cativas ou livres:

Seus senhores Ihe não podem impedir o matrimônio, nem o uso dele em tempo e lugar conveniente, nem por este respeito os podem tratar pior, nem vender para outros lugares remotos, para onde o outro, por ser cativo, ou por ter outro justo impedimento o não possa seguir. ${ }^{58}$

D evemos concluir por meio da leitura desse documento, que a I greja estendia o sacramento do matrimônio aos escravos. É importante ressaltar que na pesquisa realizada apenas nesse documento há expresso consentimento nessesentido. $\mathrm{N}$ ão aparecenas $\mathrm{O}$ rdenações do Reino nenhuma menção ao tema, tampouco nas leis canônicas de Trento há qualquer tipo de observação acerca das associações conjugais entre cativos, nem proibindo, nem permitindo. 0 silêncio éa tônica.

\subsection{A realização do sínodo baiano}

Consta queas Constituições do Arcebispado da B ahia vinculavam-se ao regime do Padroado régio que, com a instalação em 1532 da M esa da Consciência eO rdens, existiu no Brasil, segundo o qual o aparelho eclesiástico afigurava-se mais como um setor da administração do Estado português e submetia-se à autoridade do Rei. 0 Bispo e sua câmara episcopal cuidavam das causas de cunho religioso ecivil, constituindo-sena primeira instância do Juízo eclesiástico. ${ }^{59}$

A pós a criação da Província Eclesiástica da Bahia, com quatro D ioceses Sufragâneas (Rio deJaneiro, O linda, S. Tomé, Angola), o Arcebispo D om Sebastião M onteiro da Vide decidiu convocar o 10 Concílio Provincial para a Festa de Pentecostes de 1707, lançando-se ardorosamente aos seus preparativos. D adas as adversidades do período, houveausênciasimportantes: as sedes de $O$ linda eS. Tomé estavam vagas, o Bispo do Rio de Janeiro adoeceu bastante gravemente. Embora a contragosto, $0 \mathrm{M}$ etropolita fez então com o seu clero, um sínodo do Arcebispado da Bahia, o qual contou com a presença do jovem Bispo de Angola, D om Luis Simões Brandão. 
Essa assembléia transformou-se no acontecimento mais importante na organização da I greja colonial. N essa reunião, aprovaram-se as C onstituições Primeiras do Arcebispado da Bahia, ${ }^{60}$ o maior monumento de legislação eclesiástica da colônia, que se constituiu na base legal defuncionamento detodos os bispados do Brasil. Compilação formada por cinco livros (Fé, Sacramentos, Clero, I rregularidades e Penas) e 279 títulos, as C onstituições Primeiras reafirmavam o Concílio tridentino. Publicadas em Coimbra e incluídas na Coleção dos Concílios de M ansi, foram muito apreciadas e aos poucos aceitas como legislação nas demais $D$ ioceses do Brasil, não só nas Sufragâneas da Bahia, mas também em outros Bispados sucessivamente criados, como M ariana eSão Paulo. Em 1835, apresentouseatéa proposta defazer aprovar pela Santa Séas "C onstituiçõesPrimeiras da Bahia" paratodaal greja do Brasil. 0 RepresentantePontifício apoiou a idéia. ${ }^{61}$

As ConstituiçõesPrimeiras do Arcebispado da Bahiativeram vidalonga. Instituídas em 1707, atravessaram o século XIX como referência legal de matrimônio. Entretanto, no decorrer do dezenove houve mudanças importantes. A Lei 1.144, de 11/09/1861, estabeleceu o reconhecimento da união entrepessoasnão católicas, realizados conformeareligião dosnubentes. Com efeito, criou-se um registro civil para solucionar esses casos. Regulamentando a citada lei, o D ecreto 3.069, de 17/04/1863, cuidou dos nascimentos, casamentos e óbitos de pessoas oriundas de outro credo religioso que não o católico. Assim, o Brasil passou a contar com três formas de enlace matrimonial: a) o católico, observando-sea disciplina tridentina; b) o misto, mesclando credos; e c) não católico, conforme a Lei 1.144 de 1861. A proclamação da República, entretanto, colocará termo à sobrevivência do casamento religioso como regra no Brasil. U m decreto deautoria de Rui Barbosa, $n^{\circ} 181$, de 24/01/1890, determinou a validade somente do casamento civil, in verbis:

Art. 108. Esta lei começará a ter execução desde 0 dia 21/05/1890, e desta data por diante só serão considerados válidos os casamentos celebrados no Brasil que forem de acordo com suas disposições.

$\S$ Ú nico. 0 casamento civil, único válido nos termos do Decreto 181 de 24 de janeiro último, precederá sempre às cerimônias religiosas de qualquer culto, com que desejem solenizá-la os nubentes. 
Essa precedência declarada em norma jurídica disparou um processo que se consolidaria com a Constituição de 1891, separando o Estado e a I greja. Assim, encerrava-se a sobrevida das Constituições Primeiras como referência do matrimônio no Brasil. ${ }^{62}$

\subsection{0 matrimônio de escravos no Brasil}

D e todo modo, o matrimônio de escravos, como vimos, na maior parteda existência dessa forma de servidão no Brasil, foi regulado exclusivamente pelas Constituições Primeiras do Arcebispado da Bahia. Tal D ireito Canônico seguia o modelo definido por Trento no que diz respeito aos sacramentos, incluindo os cativos entre os que deveriam recebêlos, desdeo batismo até a catequese. 0 T ítulo II determinava que "São obrigados os pais, mestres, amos e senhores a ensinar ou fazer ensinar a doutrina christã aos filhos, discípulos, criados, e escravos". Já o Título XXXVII incluía os cativos no rol dos confessados. Todavia, tratava a matéria do matrimônio separadamente. D o T ítulo LXII “D o sacramento do M atrimônio: da Instituição, $M$ atéria, Forma, eM inistro deste Sacramento, dosfins para quefoi instituído, e dos efeitos que causa" até o T ítulo LXX "D o matrimônio dos vagabundos, edos quefingem casados com mulheres, quetrazem consigo, e dos que não fazem vida com as suas", existiam poucas menções aos cativos. Percebe-senesses títulosuma nítida preocupação em reafirmar as decisões de Trento em relação à finalidade do matrimônio como o remédio contra a concupiscência, jáqueseu efeito era "causar graça". ${ }^{63}$

Verifica-se ainda a preocupação em estabelecer a idade mínima para os nubentes, a saber, 14 anos para os homens e 12 anos para as mulheres; admoestação quanto à averiguação dos impedimentos matrimoniais e a obrigatoriedade do casamento a ser feito pelo próprio pároco do local e diante de testemunhas, estabelecendo ainda o ritual da cerimônia com as perguntas e respostas esperadas pelos noivos eo papel do pároco na confirmação das vontades individuais manifestadas. O Título LXXI "M atrimônio dos Escravos" disciplinava o tema, garantindo deforma bastanteampla tal direito aos cativos, buscando assegurar queo senhor não impedissenem negassetal direito ao escravo, além de proteger a vida conjugal dos cativos, a qual não podia ser perturbada por maus-tratos nem pela vendaisolada de um dos cônjuges. 0 texto é categórico ao afirmar que: 
[os senhores] tomam sobre suas consciências as culpas de seus escravos que por meio do temor se deixam muitas vezes estar, e permanecem em estado de condenação. Pelo que lhe mandamos, e encarregamos muito, para que não Ihes ponham impedimentos aos seus escravos para se casarem, nem com ameaças, e mau tratamento lhes encontrem os usos do $M$ atrimônio em tempo, e lugar conveniente, nem depois de casados Ihes vendam para partes remotas de fora para onde suas mulheres por serem escravas ou terem outro impedimento legítimo não os possam seguir. ${ }^{64}$

N os trechos seguintes reafirma-se o modelo de matrimônio definido nos títulos anteriores com iguais obrigações, sobretudo no que tange ao conhecimento da doutrina e da finalidade do casamento. 0 padre $M$ anoel Ribeiro Rocha retomou a questão do casamento cativo em seu Etíope Resgatado ${ }^{65}$ por meio de um discurso teológico-jurídico publicado em 1758. N a sétima parte intitulada "do que respeita à instrução nos bons costumes", R ocha reforçava os decretos e cânones das C onstituições da Bahia, no que diz respeito ao combate do concubinato eà liberdade de conjúgio. O rientando os senhores sobre tais temas, afirma:

E sendo caso, que lhe conste do concubinato de algum deles, têm obrigação de 0 evitar por todos os modos possíveis, dos quais o melhor é 0 Casamento, como se declara nas Constituições, a qual nesta matéria diz, e resolve completamente 0 ponto.

[...] tenham mais entendido os ditos possuidores dos cativos, que eles podem casar, com quem Ihes parecer; e que não Ihe podem impedir 0 $M$ atrimônio [...] porque isto é pecado mortal; e além disto os tais possuidores tomam sobre si, e suas consciências, todos os pecados de incontinência, e os mais, que se seguirem; como declara a dita Constituição. ${ }^{66}$

Ao contrário da historiografia que negava a constituição da família escrava no Brasil, a leitura dessa legislação canônica permite-nos duvidar de que as al tas hierarquias não reconhecessem a legitimidade do matrimônio entre escravos. Contudo, forçoso é reconhecer que tais normatizações vieram combater os impedimentos criados pelos senhores ao en lace de cativos. Ademais, pareceu preocupar às autoridades eclesiásticas a não-observância dos princípios da fé católica no ato de união conjugal entre os escravos. 
Tudo isso leva a crer que a sociedade brasileira possuía segmentos preocupados com o assunto e empenhados em adequar as práticas cotidianas do cativeiro ao regimetridentino.

\subsection{Da Legislação ao cotidiano: incursões sobre o matrimônio de escravos}

Por meio de pesquisa nos arquivos da C úria D iocesana deV itória/ES, encontraram-se registros de casamento entre escravos e de escravos com livres, em que se percebe a preocupação em acatar o modelo especificado pelas $C$ onstituições $B$ aianas. $O$ bserve se o registro de um conúbio entre escravos e a citação à Lei do Bispado:

Aos dez dias do mês de Fevereiro do anno de mil oitocentos e sessenta e hum nesta I greja matriz desta freguesia de Vianna, pelas duas horas da tarde, em minha presença e das testemunhas abaixo assignadas, predispostos na forma da Lei do Bispado, se receberão em matrimonio Bernardino e U rsula, escravos de Sebastião Pinto da Conceição. Confere-lhes as bênçãos matrimoniais para constar fiz termo que assignei.

Vigário João Pinto Pestana

Testemunhas: Joaquim de Freitas Lira e Antônio Ferreira dos Passos ${ }^{67}$

O utro testemunho no mesmo sentido:

Aos quatorze dias do mês de Abril do anno de mil oitocentos e sessenta e hum nesta matriz da freguesia de N ossa Senhora da Conceição de Vianna, a huma hora da tarde, em minha presença e das testemunhas abaixo assignadas, se receberão em $M$ atrimonio por palavras de presente preparados na forma de Lei do Bispado, J oão e Victoria, pretos, escravos de Raphael Pereira de Carvalho. Conferi-Ihe as bênçãos na forma de Rito da I greja e para constar, fiz este termo, que assignei.

Vigário João Pinto Pestana

Testemunhas: M anoel Correia da Rocha e Joaquim Carneiro Lira ${ }^{68}$

Vale ressaltar que, para além das regras do matrimônio, as Constituições Baianas orientavam os senhores a respeitarem o desejo dos cativos de unirem-se. A existência de uma doutrina legitimadora das relações conjugais entre cativos parecedemonstrar a preocupação da I greja em regulamentar as associações maritais de escravos, confirman do a tese de existência de rela- 
ç̃̃esfamiliares entre cativos, ainda quenão sancionadas oficialmente. Como bem ressaltou Florentino e Góes:

Índices marcantes de ilegitimidade não eram características exclusivas da população escrava. [...]. Apesar dos esforços da Igreja pós-tridentina, obcecada em normatizar e controlar a vida de seu rebanho, sedimentados costumes (antes consignados inclusive nas 0 rdenações do Reino, na figura do casamento "presumido") continuavam a ser teimosos adversários, aos quais dificilmente aderiam as imprecações e ameaças dos párocos mais ciosos no cumprimento das disposições conciliares. ${ }^{69}$

Vejamos o exemplo deum homem livre casando-se com uma filha de um escravo:

Aos vinte dois dias do mês de Setembro do anno de mil oitocentos e sessenta nesta M atriz de Vianna, em minha presença e das testemunhas abaixo assignadas, pelas dez horas da manhã, preparados na forma da lei do Bispado se receberão em matrimonio por palavras de presente Torquato $M$ artins de Araújo e Elena M aria do Rosário, elle filho legitimo de João Braz da Victoria e Joana Braz da Victoria, e ela filha legitima de Luiza Teixeira da Conceição e M arcelino escravo de Joaquim de Almeida Coutinho receberão logo as bênçãos matrimoniais, do que para constar, fiz termo que assignei.

Vigario João Pinto Pestana.

Testemunhas: João $M$ anoel $N$ unes e Sebastião de Freitas Lira ${ }^{70}$

Esse testemunho, repetido várias vezes entre os enlaces registrados na Paróquia deV itória/ES, mostra a ausência de restrição ao casamento misto no Brasil, ao contrário do que severifica em outras sociedades escravistas da América. $N$ as colônias inglesas da América, a restrição aos desposórios mistos dava-se segundo o binômio branco-negro:

H ouve um tempo logo após a introdução de trabalhadores escravos nos campos de tabaco da Virgínia, em que eles chegaram a se casar com brancas - vários casos documentados sobreviveram [...]. Parece que, nos primeiros dias da colonização, quando a condição social dos escravos era incerta (afinal de contas, não havia escravos na Inglaterra), os africanos eram tratados quase como os serviçais contratados, havendo pouca distância social entre criados brancos e escravos negros. M as assim que a 
instituição da escravidão evoluiu e os escravos tornaram-se cada vez mais desumanizados, um tabu contra relações sexuais e casamentos com negros e índios se estabeleceu [...]. N as colônias americanas não havia condição social intermediária designada às crianças de não-brancos e brancos. Entretanto, na Flórida e Lousiana, onde as regras espanholas e francesas prevaleciam, os mulatos eram reconhecidos como membros de uma classe própria, com muitos dos direitos dos brancos, pelo menos até 0 século $X I X$, quando quase todos os EU A aprovaram leis proibindo casamentos entre pessoas negras, brancas e negras ou mulatas. ${ }^{71}$

D e qualquer modo, parece que as exortações das Constituições Primeiras surtiram escasso efeito. A pesar da preocupação da I greja em disciplinar a maridagem dos cativos no Brasil, verifica-se com maior freqüência uniões escravas consangüíneas entre, sobretudo, mães e filhos. Em conformidade com tal perspectiva, Russell-Wood afirma que:

Estudos recentes têm revisado nossas visões sobre a composição da família no Brasil colonial. 0 que tem surgido é a diversidade da estrutura familiar e que a sanção de casamentos por parte da igreja não exerceu uma pressão bastante forte em si mesma para manter unidas as famílias. N esta discussão sobre famílias, [...] D onald Ramos constatou que a família matrifocal era a unidade familiar predominante, que as mulheres não-brancas eram as responsáveis pela maioria das unidades domésticas $[\ldots]]^{72}$

Ao que tudo indica, os senhores permaneciam como alvo de preocupação dos clérigos como obstáculos a serem transpostos para a realização do matrimônio de escravos segundo os costumes tridentinos:

... os proprietários aceitavam as uniões consensuais como ocorrência na ordem natural das coisas e tendiam a não interferir com os cativos a esse respeito ou a arranjar as uniões sem a ajuda do clero. O s clérigos, naturalmente, achavam tal comportamento irresponsável e repreensível [... $]^{73}$

$\mathrm{N}$ a prancha intitulada C asamento de negros escravos de uma casa rica, D ebret tece o seguinte comentário:

É igualmente decente e de bom-tom nas casas ricas do Brasil fazer casarem-se as negras sem contrariar demasiado suas predileções na escolha de um marido; este costume assenta-se na esperança de prendêlos me- 
Ihor à casa. [...] $\mathrm{N}$ a cerimônia do casamento é o criado de categoria superior que serve de padrinho ao inferior e N ossa Senhora é a madrinha de todos. ${ }^{74}$

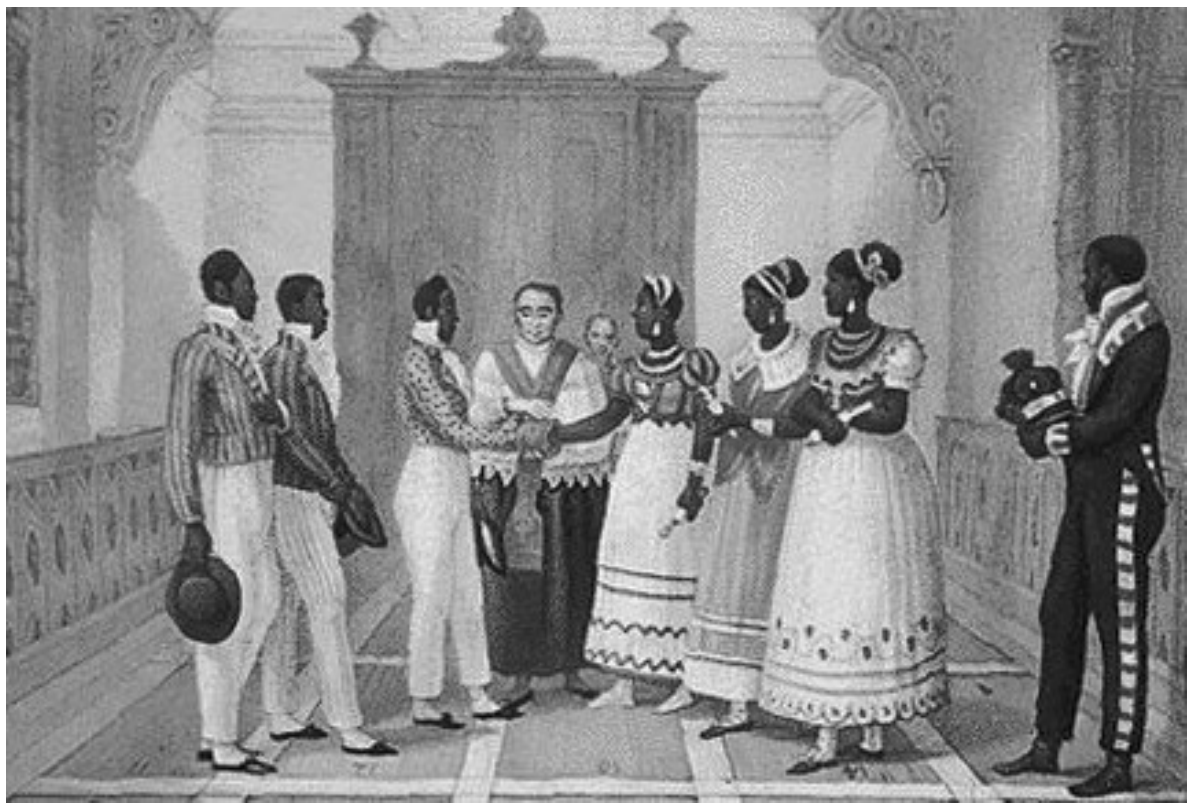

Parece que essa cena imortalizada pelo pintor francês encarna o ideal eclesiástico preconizado pelas Constituições Primeiras, destacando o ponto nodal da escravidão brasileira que, sepor nenhum momento deixou de ser violenta e opressora, por outro utilizou-se de recursos imprevistos por outras sociedades escravistas da América. $\mathrm{N}$ essas plagas, os herdeiros do colonialismo portuguêsusaram osmais diversosinstrumentos deescravização. Talvez por isso o matrimônio entre escravos segundo as normas tridentinas ganhou destaque especial em um documento canônico brasileiro. N ão se concebia deixar essa relação entre escravos escapar ao controle da sociedade escravista.

Um exemplo nessa perspectiva é a escravaria do Reverendo Torquato $M$ artins de Araújo, padree proprietário de engenhos de cana ealgodão em V itória/ES, além de uma gama de outrosnegócios: trapiches, lojas, depósi- 
tos e escravos especial izados. $\mathrm{N}$ em todo trabal ho demandado em suas propriedades carecia de braços jovens ou masculinos, como o eito. M uitas mulheres $(63,5 \%)$ eram empregadas na tecelagem do fio deal godão, onde poderiam inclusive trabalhar com seus filhos por perto; outras, em trabaIhos domésticos. Parte significativa dos escravos em idade entre 14 e 40 anos trabalhava nas fazendas. D ezessete deles eram homens com ofício e prestavam serviços na $V$ ila de V itória, de casa em casa, nas lojas ou depósitos. Inclusive, oito desses escravos especializados eram filhos que haviam aprendido o ofício com seus pais, outros três cativos especializados, em vias de comprar suas alforrias, tinham como condição no testamento treinar, cada um, dois outros escravos, para que então gozassem sua liberdade. $A$ idade dosfilhos varia de 0 a 25 anos, com a maior concentração na faixa de 0-14 anos. Há na fonte indícios de que a grande parte das crianças seja constituída por netos de africanos nascidos no cativeiro. Um indicativo concreto éque, entre as cinco angolas com mais de 50 anos, três são avóse convivem com seus filhos e netos. ${ }^{75}$

0 inventário do Reverendo, aberto no dia 21 de fevereiro de 1827, apresenta um total de 129 escravos, dos quais apenas $11,6 \%$, angolas. D o total de cativos, 106 são aparentados. Esses 106 aparentados compõem 23 famílias nucleares. I nteressa destacar o fato de todos os pares serem constituídos por uniões legítimas, isso significa uniões realizadas conforme as orientações das Constituições Baianas. D essemodo, esse padree senhor de escravos colocou em prática o sumo desejo dos clérigos brasileiros de direção do matrimônio seja entrelivres, seja entre escravos.

\section{Considerações finais}

Embora Portugal trouxesse para o Brasil uma tradição jurídica com larga experiência escravista, no campo das relações familiares a I greja e o direito canônico assumiram a responsabilidadeem disciplinar tal matéria. A importância desse assunto inscreve-seno debate acerca do papel dafamília entre cativos no Brasil, não só para comprovar a existência dessas relações, como também para enriquecer o conhecimento acerca dessa forma de sociabilidadeainda pouco trabal hada na historiografia nacional. N esse sentido, 
o presente artigo propôs-se a realizar a tarefa de identificar as principais fontes legais acerca do matrimônio de escravos.

Como vimos, a legislação laica portuguesa ocupa lugar secundário na normatização do casamento, especificamente da união de escravos. Pudemos constatar que a partir do Concílio de Trento o conúbio foi elevado à condição de sacramento para regrar a lasćivia entreos cristãos, ri-tualizandose 0 ato do casamento, que então passou a ocupar um lugar de honra ao lado dos demais sacramentos. Inspirados nessanova mentalidade reformadora dos hábitos cristãos, os clérigos brasileiros criaram as C onstituições Primeiras do Arcebispado da Bahia, nas quaisseincluiu o casório de escravos como um assunto da I greja.

A despeito das resistências senhoriais, que se interessavam pelo uso cada vez mais proveitoso e menos humano de seus cativos, a I greja imiscuiu-se nesses assuntos à época considerados privados, estabelecendo mais do que regras de sacramento, na verdade veiculando em seus cânones recomendações e orientações de tratamento aos escravos, tal qual o respeito, dentro do possível, à indissolubilidade da família, mesmo a cativa. Inde pendentemente de o casamento ter setransformado em um instrumento de pacificação das senzalas, não se podeignorar a importância do reconhecimento da I greja e de esse direito amparar também o escravo, reservando-lheum relevanteinstrumento desocial ização na sociedadeescravista vigente.

\section{Referências:}

\section{Fontes Primárias}

ARQUIVO da Cúria M etropolitana do Espírito Santo. Livro de Casamento da Freguesia de N ossa Senhora da Conceição de Vianna, (1859-1873), nº 2. CONSTITUIÇÕES primeiras do arcebispado da Bahia feitas e ordenadas pelo ilustríssimo e reverendíssimo senhor $D$. Sebastião $M$ onteiro da Vide, 50 arcebispo do dito Arcebispado, e do Conselho da Sua M ajestade: propostas, e aceitas em o Sínodo Diocesano, que o dito senhor celebrou em 12 de junho do anno de 1707. Lisboa 1719 e Coimbra. 1720. São Paulo: Typographia 2 de dezembro de Antônio Louzada Antunes, 1853.

DEBRET, J. B. Viagem Pitoresca e Histórica ao Brasil. Belo Horizonte: Ed. Itatiaia Limitada, 1978. 
O rdenações Filipinas. Livro IV. Diponível em: $\measuredangle$ http://www.uc.pt/ihti/proj/ filipinas/L4P871.HTM >. Acesso em: 25 mar 2005.

ROCHA, M anoel Ribeiro. Etíope resgatado: empenhado, sustentado, corrigido, instruído e libertado. Discurso teológico-jurídico sobre a libertação dos escravos no Brasil de 1758. Petrópolis: Vozes, [1758]1992.

\section{Livros, periódicos e teses}

AD O RN O, Sérgio. Os aprendizes do poder: 0 bacharelismo liberal na política brasileira. Rio de Janeiro: Paz e Terra, 1988.

CAM PO S, Adriana Pereira. Nas barras dos tribunais. Direito e escravidão no Espírito Santo do século XIX. Tese de D outorado defendida no Programa de Pós-Graduação Stricto Sensu em História Social da UFRJ/IFCS. Rio de Janeiro. 2003.

BARBO SA FILH O, Rubem. Tradição e artifício: iberismo e barroco na formação americana. Belo H orizonte: UFM G, 2000.

CAH ALI, Youssef Said. D o casamento. . Enciclopédia Saraiva do D iréto. São Paulo: Revista dos Tribunais, 1993.

CARD O SO , Ciro Flamarion S. Agricultura, escravidão e capitalismo. Petrópolis/ RJ: Vozes, 1979.

CURA, Antônio Alberto Vieira. Direito Romano e história do D irei to Português: casos práticos resolvidos e textos. Lisboa: Coimbra Editora, 1995.

D AVID, René. Os grandes sistemas do direito contemporâneo. São Paulo: M artins Fontes, 1986.

D AVID SO N, N. S. A Contra-Reforma. São Paulo: M artins Fontes, 1991.

D ELU M EAU, Jean. A civilização do renascimento. Lisboa: Editorial Estampa, 1984.

ELKIN S, Stanley. Slavery: a problem in a American institutional and intellectual life. Chicago: University Chicago Press, 1959.

FARIA, S. de C. A colônia em movimento: fortuna e família no cotidiano colonial. Rio de Janeiro: N ova Fronteira, 1998.

FARIA, Sheila Siqueira de Castro. Casamento. In: VAIN FAS, Ronaldo. Dicionário do Brasil colonial: 1850-1808. Rio de Janeiro: 0 bjetiva, 2000.

FLAN D RIN , Jean-Louis. Famílias, parentesco, casa e sexualidade na sociedade antiga. Lisboa: Estampa, 1991. 
FLORENTIN O, M anolo; GÓES, José Roberto. A paz das senzalas: famílias escravas e tráfico atlântico, Rio de Janeiro, c.1790-c.1850. Rio de Janeiro: Civilização Brasileira, 1997.

GILISSEN , J. Introdução histórica ao direito. 3a ed. Lisboa: Fund. Calouste Gulbenkian, 2001.

GRIN BERG, Keila. Código Civi e cidadania. 2ª ed. Rio de Janeiro: Jorge Zahar, 2002.

KRAM ER, H einrich; SPREN GER, James. M alleus M aleficarum: 0 martelo das feiticeiras. 14a ed. Rio de Janeiro: Record, 2000.

LACO M BE, Américo Jacobina. A cultura jurídica. In: HOLANDA, Sérgio Buarque de. História geral da civilização brasileira. 5ạ ed. São Paulo: Difel, 1985. Tomo II, vol 3.

LEITE, Eduardo de O liveira. Tratado de Família: origem e evolução da família. Curitiba: Juruá, 1991.

LOPES, J.R.L. 0 direito na história. 2ª ed. São Paulo: Max Limonad, 2002. MARILYN YALON. A história da esposa: da virgem M aria à madona - papel da mulher casada dos tempos bíblicos até hoje. Rio de Janeiro: Ediouro, 2002. M ATTOS (de CASTRO), H ebe M aria. D as cores do siêncio. O s significados da liberdade no sudeste escravista. Brasil, séc. XIX. Rio de Janeiro: N ova Fronteira, 1998.

M ERLO , P. M. S. À sombra da escravidão: negócios e família escrava em Vitória/ ES, 1800-1830. D issertação defendida no Programa de Pós-graduação da Universidade Federal Fluminense. Niterói, 2003.

M ORAES, D ouglas Batista de. A I greja: o "baptismo", o casamento e a angústia do confessionário. M neme, v.5, n.2, out/nov 2004

N ADER, M aria Beatriz. M udanças econômicas e relações conjugai s: novos paradigmas na relação mulher e casamento. Vitória (ES), 1970-2000. (D outorado em H istória) - Faculdade de Filosofia, Letras e Ciências H umanas, Universidade de São Paulo, São Paulo, 2003, p.52.

REIS J.J. (O rg.) Escravidão \& invenção da liberdade. "Estudos sobre o negro no Brasil". São Paulo: Brasiliense, 1988.

RUCQU O I, Adeline. História medieval da Península I bérica. Lisboa: Editorial Estampa, 1995. 
RUSSELL-W O OD, A. J. R. Através de um prisma africano: uma nova abordagem ao estudo da diáspora africana no Brasil colonial. In: Revista Tempo. N 012 , Rio de Janeiro: 7Letras, 2002.

SILVA, J. J. de Andrade e (org.). Coleção cronológica da legislação portuguesa. Lisboa: 1855-1859.

SILVA, M aria Beatriz Nizza da. Cultura no Brasil Colônia. Petrópolis: Vozes, 1981.

TAN N EN BAU M , Frank. Slave and Citizen. N ew York: Vintage Books, 1946. VAIN FAS, Ronaldo. Trópicos dos pecados: moral, sexualidade e inquisição no Brasil. Rio de Janeiro: N ova Fronteira, 1997.

VALLAD ÃO, H aroldo. História do direito, especialmente do direito brasileiro. 3. ed. Rio de Janeiro: Livraria Freitas Bastos S. A., 1977.

WATSO N, Alan. Slave law in the Americas. Athens: University of Georgia Press, 1989.

WEH LIN G, Arno; W EH LIN G, M aria José. Formação do Brasil colonial. Rio de Janeiro: N ova Fronteira, 1994.

\section{Notas}

${ }^{1} \mathrm{~N}$ o final da década de cinqüenta, pesquisadores tentaram estabelecer uma rel ação entreo passado escravista eas relações raciais das sociedades americanas. H ouveuma primeira geração de estudiosos que sustentou a tese da distinção entre os sistemas escravistas na América de acordo com o tratamento dado aos escravos (CARD O SO , Ciro Flamarion S. A gricultura, escravi dão ecapitalismo. Petrópolis/RJ: Vozes, 1979. p. 95 a 108).

2TAN N EN BAU M , Frank. Slaveand Citizen. N ew York: VintageBooks, 1946.

${ }^{3} \mathrm{O}$ utros estudiosos mantiveram-se atados à tese da diferenciação deacordo com a potência colonizadora, como defendeu Stanley Elkins, argumentando quea escravidão nosEstados U nidosfoi conseqüência deum capitalismo sem barreiras paraa exploração do escravo. Jána América Latina, al greja, entre outrasinstituições, teria impedido o tratamento desumano dos cativos (ELKIN S, Stanley. Slavery: a problem in a American institutional and intellectual life. Chicago: U niversity C hicago Press, 1959).

${ }^{4}$ TAN N EN BAU M , 1946, p. 88 e 89 [tradução dasautoras].

${ }^{5}$ Sobreo assunto ver: AD O RN 0 , Segio. 0 saprendizesdo poder: 0 bacharelismo liberal na política brasileira. Rio deJaneiro: Paz eTerra, 1988.

${ }^{6}$ TAN N EN BAU M, 1946.

${ }^{7}$ Lei de 20 deoutubro de 1823 quereiterava a vigência dasleis portuguesas atéa organização dosnovos códigos ou alterações em dispositivos específicos. 
${ }^{8}$ W EH LIN G , Arno; W EH LIN G, M ariaJ osé. Formação do Brasil colonial. Rio de aneiro: N ova Fronteira, 1994, p. 302.

${ }^{9}$ O sportuguesespromulgaram seu Código C ivil em 1867, enquanto no Brasil as ordenações somente foram suplantadas pelo Código Civil em 1916. Sobre o assunto conferir em GILISSEN , John. Introdução histórica ao di reito. 3. ed. Lisboa: Fund. CalousteG ulbenkian, 2001. p. 457 eG RIN BERG , Keila. Código Civi ecidadania. 2a. Ed. Rio deJ aneiro: J orge Zahar, 2002.

${ }^{10}$ LACO M BE, Américo Jacobina. A cultura jurídica. In: H O LAN D A, Sérgio Buarquede. H isória geral da civilização brasileira. 5. ed. São Paulo: D ifel, 1985. Tomoll, vol 3, p.15.

${ }^{11}$ Valemencionar as 0 rdenações Afonsinas, as primeiras da tríade A fonsinas-M anoelinasFilipinas, que comandava no livro II, título $9^{\circ}$ : Estabel ecemos, e poemospor Ley, quequando al guum caso for trazido em pratica, queseja determinado per al guma L ey do regno, ou estillo da nossa Corte, ou custumedosnossosRegnosantigamenteusado, sja per ellesjulgado, edesembargado finalmente, nom embargantequeasL eyx I mperiaaes [D ireito Romano] acerca do di to caso ajam desposto em outra guisa, porqueondea Ley do Regno dispõem, cessam todalasoutras Leys, eD ireitos, equando o caso, de quese trauta, nom for determnado per Ley do Regno, mandamos que seja julgado, efindo pelasL eyx I mperiaaes epelos Santos Cânones (CU RA, Antônio Alberto Vieira. D ireito Romano e história do D ireito Português casos práticos resolvidos e textos. Lisboa: CoimbraEditora, 1995).

${ }^{12} \mathrm{Cf}$. RU CQ U O I, Adeline. H istória medieval da Península I bérica. Lisboa: Editorial Estampa, 1995. p. 250-272.

${ }^{13}$ BARBO SA FILH O , Rubem. Tradição eartifício: iberismo ebarroco na formação americana. Belo H orizonte: U FM G, 2000.

${ }^{14} \mathrm{O}$ breviário deAlarico desempenhou no 0 cidenteem escala menor o papel atribuído àobra deJ ustiniano no $O$ riente. Foi freqüentemente copiado atéo século IX eX. Elaboraram-se numerosos resumosnos séculos VII eVIII, por exemplo epítomeaegidii, epítomeparisiensis, epítomemonachi. [...]. 0 Breviário deAlarico pareceter sido adotado em todo o Império Franco, impôs-se mesmo na região dos Burgúndios, desde o fim do século VI, invés da Lex romona burgundionum. (Cf. GILISSEN , 2001. p.170).

${ }^{15} \mathrm{O}$ F uero J uzgo para os moçárabes, o Fuero del conquistador para os companheiros queali ficaram morando, o dosfrancos, o Alcorão e o Talmud para sarracenos ejudeus.

${ }^{16} \mathrm{AsSiete}$ Partidasnão éum contumier, masantes uma recolha dos actos legislativos deC astela e Leão, completada por numerosos recursos ao direito romano eao direito canônico. Sob os nomes, sucessivamente, deEspeclo, de libro de fuero, delibro delas leys, os redatores-juristas da corte de Afonso X, o Sábio, e depois de Fernando IV - dela fizeram uma vasta obra de doutrina do direito, na qual o direito consuetudinário local équase inteiramente substituído por uma exposição do direito erudito; encontra-seaí por enquanto empréstimo retirado do librefeudorum e dos roles d'O lèron. Afonso, o Sábio, não tinha, contudo, chegado a impor esta compilação de direito em todo seu reino; peranteo protesto geral, tinha sido obrigado a confirmar em 1272, os privilégios eforos locais. Assiete partidastiveram, no entanto, uma 
grande influência e contribuíram grandemente para a romanização do direito espanhol. Conhecem-se dezenas de edições ainda na época moderna (GILISSEN , 2001, p. 269). ${ }^{17}$ VALLAD ÃO , H aroldo. H istória do di reito, especialmentedo direito brasile ro. 3e ed. Rio de Janeiro: LivrariaFreitas BastosS. A., 1977. p. 44.

${ }^{18}$ RU CQ U OI, 1995, p. 252.

${ }^{19}$ Conferir as notas produzidas por Antônio M anuel H espanha na obra de GILISSEN , J ohn. Introdução histórica ao direito. 3. ed. Lisboa: Fund. C alousteG ulbenkian, 2001. p. 319.

${ }^{20} \mathrm{Cf}$. WATSO N, Alan. Slavelaw in theAmericas Athens: University of G eorgiaPress, 1989. 0 autor admiteessa possibilidadesomentesefor considerado o C ódigo Visigodo que, entre tanto, não chegou a ser usado.

${ }^{21}$ WAT SO N , 1989, p. 92-93.

${ }_{22} \mathrm{~N}$ este sentido, conferir, por exemplo, nas O rdenações Filipinas, OTÍT U LO XVI - D o que dorme com a mulher, queandano Paço, ou entra em casa dealguma pessoa para dormir com mulher virgem, ou viúva honesta, ou escrava branca deguarda. p.1165-66; C orrespondênciano T ítulo XXIII das O rdenações $M$ anuelinas. Conferir ainda, nas O rdenaçõesFilipinas, 0 TÍT U LO XIX - D o homem, que casa com duas mulheres, eda mulher, que casa com dous maridos. [sic], p. 1170-71; Correspondência: Título XIII das O rd. Afonsinas eT ítulo XIX das 0 rd. M anuelinas. Cf. SI LVA, J. J. deAndradee (O rg.). C oleção cronológica da legis lação portuguesa. Lisboa: 1855-1859.

${ }^{23}$ GILISSEN , 2001, p. 91.

${ }^{24}$ U LPIAN O , D igesto, 35, I, 1 apud GILISSEN , 2001, p. 565.

${ }^{25}$ LEITE, Eduardo deO liveira. TratadodeFamília: origem eevoluçãoda família. Curitiba: Juruá, 1991. p. 210 eM ARILYN YALO N . A história da esposa: da virgem M aria à madona - papel da mulher casada dostemposbíblicosatéhoje Rio deJ aneiro: Ediouro, 2002. p.68-69.

${ }^{26}$ GILISSEN , 2001.

${ }^{27}$ Essa teoria vinculava-se ao texto de G ênesis (II, 24) Erunt duo in carneuma (serão dois numa só carne) - GILISSEN , 2001, p. 570.

${ }^{28} \mathrm{CAH}$ ALI, Youssef Said. D o casamento. . Encidopédia Saraiva do D irei to. São Paulo: Revista dosTribunais, 1993. Vol 13, p. 9-19 eFARIA, Sheila Siqueira deC astro. C asamento. In: VAIN FAS, Ronaldo. Dicionário do Brasil colonial: 1850-1808. Rio deJaneiro: 0 bjetiva, 2000. p.106-109.

${ }^{29}$ GILISSEN , 2001, p. 322.

${ }^{30}$ Cf. LO PES, J.R.L. 0 direito na história. 2. ed. São Paulo: Max Limonad, 2002 e DELU M EAU, Jean. A civilização do Renascimento. Lisboa: Estampa, 1984. Vol.1, p.126.

${ }^{31} \mathrm{~N}$ AD ER, M aria Beatriz. M udanças econômicas erelações conjugais, novos paradigmasna relação mulher e casamento. Vitória (ES), 1970-2000. Tese de D outorado apresentada à Faculdade deFilosofia, Letrase C iências H umanas, Universidade deSão Paulo. São Paulo, 2003. p.52.

${ }^{32}$ Cf. DELUM EAU, 1984. Vol.1, p.129. 
${ }^{33}$ D AVID SO N , N . S. A Contra-Reforma. São Paulo: M artinsFontes, 1991.

${ }^{34}$ Cf. N ADER, 2003.

${ }^{35}$ VAIN FAS, Ronaldo. Trópicos dos pecados moral, sexualidadeeinquis çãa no Brasil. Rio de Janeiro: N ovaF ronteira, 1997.

${ }^{36} \mathrm{Asregras}$ morais do cristianismo por muito tempo não conseguiram penetrar a fundo nas massas populares. A violência foi amplamenteutilizada contra essasmassas, duranteal dade M édia, emuitosnúcleos pagãos coexistiram entreos europeus cristianizados, desenvolvendo seus ritos, inclusiveo casamento. Sobreo assunto, ver KRAM ER, H einrich; SPREN GER, J ames. M alleusM al eficarum: o martelo das feiticeiras. 14. ed. Rio deJaneiro: Record, 2000.

${ }^{37}$ C aput do item 970 (D outrina sobreo Sacramento do M atrimônio) da Sessão XXIV do AgnusD ei, documento produzido pelo Concílio Ecumênico deTrento, celebrado no tempo do Sumo Pontífice Pio IV, em 11 denovembro de 1563.

38971 . Cân. I. Seal guém disser queo matrimônio não éverdadeiro epropriamenteum dos setesacramentos da Lei Evangélica, instituído por $\mathrm{N}$ osso Senhor J esus C risto, e[disser] quefoi inventado pel os homensnal greja eque não confere graça- seja excomungado [cfr. $n^{\circ} 969$ ].

972. Cân. 2. Sealguém disser queélícito aos cristãos ter ao mesmo tempo muitas mulheres, $\mathrm{e}$ queisto não éproibido por nenhumalei divina ( $\mathrm{t} 19,4$ ss 9 ) - saja excomungado [cfr. $n^{\circ} 969$ ]. 973. Cân. 3. Sealguém disser quesó aqueles graus de consangüineidadeede afinidadeque se declaram no Levítico (Lv 18, 6 ss) podem impedir de contrair matrimonio edirimi-lo depois decontraído; ou quea I greja não pode dispensar deal guns desses impedimentos ou estabelecer outros [graus] queimpeçam edirimam - seja excomungado.

974. Cân. 4. Sealguém disser queal grejanão pôdeestabelecer impedimentosdirimentes do matrimônio, equeerrou ao estabelecêlos- seja excomungado.

975. Cân. 5. Sealguém disser queo vínculo do matrimônio podeser dissolvido pelo cônjuge por motivo deheresia, demolesta coabitação ou de ausência afetada- seja excomungado.

976. Cân. 6. Sealguém disser queo matrimônio contraído masnão consumado não sedirime pela soleneprofissão religiosa de um dosesposos- seja excomungado.

977. Cân. 7. Se alguém disser que a I grejaerra quando ensinou e ensina que, segundo a doutrina evangélica eapostólica (M c 10; I C or 7), o vínculo do matrimônio não podeser dissolvido pelo adultério dum doscônjuges equenenhum dos dois, nem mesmo o inocente quenão deu motivo ao adultério, podecontrair outro matrimonio em vida do outro cônjuge, equecometeadultério tanto aqueleque, repudiadaa adúltera, casa com outra, como aquela que, abandonado o marido, casa com outro - seja excomungado.

978. Cân. 8. Sealguém disser queal grejaerra, quando determina quepor muitosmotivos se pode fazer [licitamente] separação entre os consortes quanto ao tálamo e coabitação, por tempo certo ou incerto - seja excomungado.

979. Cân. 9. Sealguém disser queos clérigos constituídosem ordenssacras eos Regulares que professam solenementecastidade, podem contrair validamentematrimonio, não obstantea lei eclesiástica ou o voto, equeo contrário disto outra coisanão ésenão condenar o matrimônio; equepodem contrair matrimônio todos os quenão sentem ter o dom da castidade, ainda 
queo tenham prometido - seja excomungado. PoisD eus não nega estedom aquem piamente Iho pede, nem consentequesejamostentadosacima dasnossasforças (I C or 10, 13).

980. Cân. 10. Sealguém disser queo estado conjugal sedeveantepor ao estado da virgindade ou celibato, equenão émelhor nem maisbeato permanecer no estado de virgindadeecelibato do quecontrair matrimônio (cfr. M t 19, 11 s; I C or 7, 25 s 38. 40) - seja excomungado.

981. Cân. 11. Seal guém disser que a proibição da solenidade dos desponsórios em certos tempos do ano é uma superstição tirânica derivada das superstições pagas; ou condenar as bênçãos eoutras cerimônias quea I greja usa neles- seja excomungado.

982. Cân. 12. Sealguém disser queascausas matrimoniais não são da competência dosjuízes eclesiásticos- seja excomungado.

${ }^{39}$ Sobreo assunto ver SI LVA, M aria Beatriz N izza da. Cultura no Brasil colônia. Petrópolis: Vozes, 1981.

${ }^{40}$ Sessão XXV (3 e4/12/1563). D isponível em: http://www.montfort.org.br/documentos/ trento.html. A cesso em: 25 mar 2005.

${ }^{41} \mathrm{O}$ s paisficaram escan dalizados por não terem sua autoridade considerada pelo C oncílio. Sobreo tema ver FLAN D RIN , Jean-Louis. Famílias, parentesco, casa esexualidadena sociedade antiga. Lisboa: Estampa, 1991. p. 157.

${ }^{42}$ Sessão XXV (3 e4/12/1563). D isponível em: http://www.montfort.org.br/documentos/) trento.html. Acesso em: 25 mar 2005.

${ }^{43}$ Seriam os casamentos real izados perto da mortede um dos cônjuges eos casamentos secretos quenão se confundiam com oscasamentos populares.

${ }^{44}$ Sessão XXV (3 e4/12/1563). D isponível em: http://www.montfort.org.br/documentos/ trento.html. Acesso em: 25 mar 2005.

${ }^{45}$ Em Portugal o D ireito C anônico possuíatanta autoridade, quechegou a predominar entre as próprias leis do reino, com D. Afonso II, eD . D iniz, quando fundou a primeira universidade portuguesa, de Lisboa, determinou o seu estudo conjunto com o romano [...]; só cessou esseprestígio da Lei daBoa Razão (1769) (VALLAD ÃO , H aroldo. H isória do D ireito especialmentedo D ireito brasileiro. $3^{a}$ ed. Rio de aneiro: LivrariaFreitas BastosS/A, 1977. p. 44).

${ }^{46} \mathrm{H}$ ESPAN H A, Antônio M anuel. N ota do tradutor apud GILISSEN , 1995, p. 322.

${ }^{47}$ Para H erculano, os casamentos eram de bênção (ad benedictionem) de pública fama (conhoçudos) ou dejuras (juras in manu clerici). Só o casamento de bênção era, segundo o autor, um casamento perfeitamentelegítimo aos ol hos da I greja, possuindo a dignidade de sacramento. 0 soutros eram, ainda segundo ele, válidos, masilegítimose desacompanhados dosefeitos deordem sobrenatural queo primeiro produzia. A suavalidadeera, portanto, uma validademeramentecivil quea I greja, então senhora de toda a legislação matrimonial, reconheciae regulava por transigência com os costumes das populações, mas procurando reprimiIos. Cf. D AVID, René. O s grandes sistemas do direito contemporâneo. São Paulo: M artins Fontes, 1986. 
${ }^{48} O$ casamento depúblicafama era uma formadeunião conjugal clandestinamente contra ída, mas que possuía a qualidade de matrimônio pela fama em queeram tidos os cônjuges, como tais, pelo público.

${ }^{49} \mathrm{O}$ casamento dejuras era outraforma intermédia com relação às anteriores, porém caracterizada pela presença, no momento da celebração, detestemunhase deum clérigo, embora essa celebração não tivesse lugar na I greja, nem revestisse as formalidades rituais do verdadeiro matrimônio religioso.

${ }^{50}$ O rdenações Filipinas. Livro IV. Diponível em: http://www.uc.pt/ihti/proj/filipinas/ L4P871.htm. Acesso em: 25 mar 2005.

${ }^{51}$ O RDEN AÇ Õ ES Filipinas. Livro V.T Título 38. Caput.

${ }^{52}$ O RD EN AÇÕ ES Filipinas. Livro V.Título XVI. Caput.

${ }^{53}$ ORD EN AÇÕ ES Filipinas. Livro V. Título XXIV. Caput.

${ }^{54}$ FARIA, 2000, p. 106-109.

${ }^{55}$ VAIN FAS, Ronaldo. Trópicos dos pecados moral, sexualidadeeinquisição no Brasil. Rio de Janeiro: N ovaF ronteira, 1997.

${ }^{56}$ VAINFAS, 1997, p. 76.

${ }^{57} \mathrm{~A}$ designação completaé: Constituições primeiras do arcebispado da Bahia feitase ordenadas pelo ilustríssimo, ereverendíssimo senhor $D$. Sebastião M onteiro da Vide, 50 arcebispo do dito Arcebispado, e do Conselho da Sua M ajestade: propostas, eaceitas em o Sínodo D iocesano, que o dito senhor celebrou em 12 de junho do anno de 1707. Lisboa 1719 e Coimbra. 1720. São Paulo:Typographia 2 de dezembro deAntônio L ouzadaAntunes, 1853.

${ }^{58}$ Constituiçõesprimé ras do arcebispado da Bahia[...]. São Paulo: Typographia 2 de dezembro deAntônio LouzadaAntunes, 1853. p.303.

${ }^{59}$ M O RAES, D ouglas Batista de. A I greja: o "baptismo", o casamento ea angústia do confessionário. M neme, v.5, n.2, out/nov 2004, p. 2.

${ }^{60}$ Além dessa compilação, erigiu-se um pouco antes o Regimento do auditório eclesiástico (1704), verdadeiro código deprocesso, deenormeimportâncianum tempo em queboa parte das causas corria no foro dal greja, havendo em cada grupo de paróquias um vigário forâneo, com poderesjudiciais, enaBahia, um tribunal (relações eclesiásticas).

${ }^{61}$ Cf. WEH LIN G, Arno \& W EH LIN G, M ariaJ oséC. de. Formação do Brasil colonial. 2a .ed. Rio deJ aneiro: N ova Fronteira, 1994.p. 81-85 eRU BERT, Arlindo. A I greja no Brasil. Santa M aria/RS: Pallotti, 1988. Vol 3, p. 231-234.

${ }^{62}$ C f BRAN D ÃO , D ébora Vanessa C aús. D o casamento religi oso com efeitos civis ao novo Código Civil. 0 N eófito: informativo jurídico. p. 4. Disponível em: www.neofito.com.br Acesso em: 25 mar 2005.

${ }^{63}$ RIBEIRÃO , Simone. Asinovações constitucionaisno D ireito de Família. Jus N avegandi, Internet.

${ }^{64}$ Constitui ções primer ras do arcebispado da Bahia, 1853, p.304. 
${ }^{65}$ RO CH A, M anoel Ribeiro. Etíoperesgatado: empenhado, sustentado, corrigido, instruídoe libertado. D iscurso teológico-jurídico sobre a libertação dos escravos no Brasil de 1758. Petrópolis: Vozes, 1992.

${ }^{66}$ Ibid., p.122 e 123.

${ }^{67}$ ARQ U IVO daCúria M etropolitana do Espírito Santo. Livro deC asamento daFreguesia deN ossa Senhora da Conceição deVianna, (1859-1873), nº 2.

${ }^{68}$ ARQ U IV O daCúria M etropolitana do Espírito Santo. Livro de Casamento daFreguesia deN ossa Senhora da Conceição deVianna, (1859-1873), n² 2.

${ }^{69}$ FLO REN TIN O , M anolo; GÓ ES, J oséR oberto. A paz dassenzalas famíliasescravasetráfico atlântico, Rio deJ aneiro, c.1790-c.1850. Rio deJ aneiro: Civilização Brasileira, 1997, p. 142.

${ }^{70}$ ARQ U IV O daCúria M etropolitana do Espírito Santo. Livro deC asamento daFreguesia deN ossa Senhora da Conceição deVianna, (1859-1873), $n^{\circ} 2$.

${ }^{71}$ YELON, p. 169-70.

${ }^{72}$ RUSSELL-W O O D , A. J. R. Atravésdeum prisma africano: uma nova abordagem ao estudo da diáspora africana no Brasil colonial. In: Revista Tempo. $N$ N 12, Rio de Janeiro: 7Letras, 2002, p. 27.

${ }^{73}$ SC H WART Z, Stuart B. Segredosinternos engenhoseescravosna sociedadecolonial. São Paulo: Companhia das Letras, 1988. p. 315.

${ }^{74}$ DEBRET, 1978, p.200.

${ }^{75}$ M ER LO , P. M . S. À sombra da escravidão: negóciosefamília escrava em Vitória/ES, 1800 1830. D issertação apresentada ao Programa de Pós-G raduação da U niversidade F ederal Fluminense. N iterói, 2003. p.106-107.

\section{RESUMO}

0 presente artigo tem como propósito discutir a legi slação a respei to de casamentos entre escravos e entre escravos e livres no Brasil do período colonial ao Império. Para tanto, levantou-se o ordenamento legal em vigor até a instauração da República, procedendo-se à leitura da legislação civil que, até 1916, obedecia ainda às ordenações portuguesas intituladas de Filipinas. Como aquela normatização lusitana fora precedida por duas outras, a Afonsina e a M anuelina, buscou-se fazer uma comparação entre esses vários diplomas legais. Além disso, procedeu-se a uma investigação a respeito do assunto nas normas eclesiásticas, sobretudo nas decisões emanadas do Concílio de Trento e nas Constitui ções Primeiras do Arcebi spado da Bahia. Tais documentos canôni cos concorriam com as disposições civis contidas nas ordenações que disciplinavam o matrimônio no Brasil desde os tempos coloniais e permaneceram influentes mesmo após a Independência. A meta foi conseguir 0 
maior subsídio possível para esclarecer alguns aspectos importantes da instituição matrimonial envolvendo cativos vigente no Brasil até o Império.

Palavras-chave: Casamento, Escravidão, Direito, Brasil

\section{ABSTRACT}

This paper aims at discussing the legislation regulating the marriage among saves as well as between slaves and free man in Brazil from colonial times to the Empire period. To do so, the body of laws on the subject until the advent of the Republic was retrieved, indicating the civilian legislation that, until 1916, still followed the Portuguese 0 rdinances named Filipinas. Since this L usitanian statute was preceded by two others, the so-called Afonsina and M anuelina codes, a comparison among them was established. Besides that, an inquiry was hold into the Ecclesiastical norms, mainly that ones from the Trento Council and the First Constitutions of Bahia's Archebishopric. Such canonical documents paralleled the civilian norms contained in the ordinances that regulated marriage in Brazil since colonial times and they kept their influence well after the Brazilian Independence. The goal was to secure the most valuable information in order to clear some important aspects on the marriage institution involving saves in Brazil until the Empire period. Key words: M arriage, Slavery, Law, Brazil.

(recebido em abril de 2005 e aprovado em junho do mesmo ano) 